\title{
Effects of Redesigned Model Eliciting Activities on Seventh Grade Students' Mathematics Success and Students' Views about These Activities
}

\author{
Mehmet Akif Karabork ${ }^{1^{*}}$, and Soner Durmus ${ }^{2}$ \\ ${ }^{1}$ Ministry of National Education, Atatürk Middle School, Bolu, Turkey, 14100 \\ ${ }^{1}$ Department of Mathematics and Science Education, Bolu Abant İzzet Baysal Universty, Bolu, Turkey, 14030 \\ *Corresponding author: mehmet_akif_karabrk@hotmail.com | Phone Number: +905423983661
}

\section{ARTICLE HISTORY}

Received : 18 September 2020

Revised : 23 September 2020

Accepted : 11 October 2020

\section{KEYWORDS}

Model eliciting activities; Mathematical model; Modelling;

Achievement;

Student's view;

\begin{abstract}
In this study, the effects of redesigned modeling activities on the academic achievement of 7 th grade students and the student's view about these activities were investigated. We use explanatory sequential mixed method design that is one of the mixed research methodology for this investigation. The quantitative part of this research established according to semi-experimental study with pre-posttest, and qualitative part of this study execute with the case study. Quantitative data were collected with multiple choice academic achievement tests, and qualitative data were collected with study papers, observation forms, forms of student's view, and semi-structured interviews at the end of all activities. The quantitative data were analyzed with covariance analysis. Qualitative data were analyzed with content analysis. As a result, a statistically significant difference was found in favor of the experimental group on the academic achievement which influenced by modeling activities. This difference has been influenced by the presentation of the learning environment in which the students' attitudes and beliefs towards themselves and the lessons will be positively affected, and mathematical skills will be supported to increase success.
\end{abstract}

This is an open access article under the CC-BY-SA license.

\section{INTRODUCTION}

One of the aims of mathematics education is to improve students' ability to transfer mathematical knowledge to the real world, mathematical literacy, using mathematical terminology and problem solving skills while communicating or advocating for own idea (Ministry of National Education) (MoNE, 2017a). Mathematical modeling perspective centered model eliciting activities provide a learning environment in which many of these skills that the curriculum aims to provide to students can be acquired (Doruk, 2010; Doruk \& Umay, 2011; Kandemir, 2011; Sandalci, 2013). Model eliciting activities are real life contexts rather than specific objectives in the curriculum (Doerr \& English, 2003; Lesh \& Doerr, 2003). What would be the effect on students, such as academic achievement, especially in the context of the specific objectives of the curriculum offered by these activities, it is the subject of curiosity. In our country we usually assess the student's achievement level with multiple choice tests. Therefore, the question of the effect of model eliciting activities, which are related to the specific objectives in the mathematics curriculum, on the academic achievement of students in standard achievement tests is at the center of this study.

Mathematical modeling has been chosen in this study because it is one of the most studied topics in recent years, it contains real life problems and it is a bridge between mathematical world and real world. Another reason for the selection of mathematical modeling is the change in the world in recent years, and this change necessitates that the mathematics taught in the school should be found in the real world. National Council of Teachers of Mathematics (NCTM, 2000) stated the this situation as that it has changed from yesterday where it is difficult to access information and calculators, to today where it is easy to access all kinds of technology and information. Individuals have the opportunity to produce unique solutions to the problems they face in the real world with easy access to information and technology. However, they need to simplify the problem situations they face in the real world, control and implement the structure they simplify and the solutions they find in the real world (Karali \& Durmus, $2015)$. In other words, in order to better understand and solve the complex problems caused by intertwined situations in the real world, individuals need to form a model that demonstrates the current situation, test the suitability of the model, and apply the solution to the real world. The term "model" is considered to be an object that can represent a phenomenon or concept and that allows the visual representation of these characteristics by carrying the features found in the phenomenon or concept it represents (Van De Walle, Karp, \& Bay-Williams, 2012). Modeling is defined as the process of establishing and optimizing the relations of these objects with the structure they are related to (Lesh \& Doerr, 2003).

Mathematical modeling is the process of analyzing and evaluating complex situations in real life and transforming them 
into a mathematical language and testing the compatibility of the structure in this language with the aim of producing a general, not specific solution (Erbas et al., 2014). Mathematical modeling is used in many disciplines, especially engineering. In the field of education, mathematical modeling is used as a facilitating "tool" for teaching or as a "context" in which teaching is conducted. Opinions that consider mathematical modeling as a "tool" in educational propose the use of mathematical modeling as a "tool" because of its features such as increasing motivation and embodying the subject in the abstraction process (Bardini \& Stacey, 2006; Pierce \& Stacey, 2006). The ideas that support the use of mathematical modeling as "context" in the educational process combine with the idea that a mathematical modeling is presented as a main scaffold or a mental structure in which students' ideas can grow with the support of the problem and propose its use as a "context" (Galbraith, 2012).

In this study, the view of Lesh and Doerr (2003) which considers mathematical modeling as a context, is adopted. This view is called contextual modeling according to the classification of Kaiser and Sriraman (2006) and is considered as an approach to solving verbal problems. However, Lesh and Doerr's (2003) approach to mathematical modeling has become more than solving verbal problems. According to the philosophical premises on which the modeling perspective is based, models are created by individuals and can be represented differently. The act of meaning is dynamic and the construction of knowledge or model is not independent of experience (Kaiser \& Sriraman, 2006). With these features, the modeling perspective has gone further without solving the verbal problem and has come to the point of presenting learning environments in which multiple solutions can emerge in an active learning effort where students build new knowledge on their previous knowledge.

In the model eliciting activities, students make sense of the situations they encounter by starting from their own experiences, transfer the meaning they have obtained into mathematical language, and put forward a general structure, constantly develop the structure that the general structure complies with the situation in the real world, and search for the solution it creates in itself (Kaiser \& Sriraman, 2006). These activities provide learning environments enriched with real life contents where each student can create a unique solution, express these solutions in different representations such as tables, graphics, equality, pictures and shapes and discuss the validity of these products (Kaput, 1987; Lesh \& Doerr, 2003).

Table 1. Principles of model eliciting activity

\begin{tabular}{ll}
\hline \multicolumn{1}{c}{ Principle } & \multicolumn{1}{c}{ Explain } \\
\hline Reality & $\begin{array}{l}\text { Modeling activity should be interesting and make } \\
\text { you feel that you are really solving problems and } \\
\text { helping someone. } \\
\text { Modeling activities should allow for the production } \\
\text { of a model with a solution or situation rather than a } \\
\text { nodel Eliciting }\end{array}$ \\
numerical result \\
Modeling activity should allow the student to \\
control his / her own work without being bound by \\
an authority. \\
Modeling activity should provide an opportunity for \\
the solutions or ideas to be based on information \\
Documentation
\end{tabular}$\quad \begin{aligned} & \text { and documentation to demonstrate their validity. } \\
& \text { The result produced in the model eliciting activity } \\
& \text { should be generalizable to similar situations. }\end{aligned}$

should be generalizable to similar situations.
Effective It should serve as a first example for similar

Prototype situations that follow the model itself generated during the model eliciting activity.

Doruk (2010) examined the effect of activities written in accordance with these principles on students' transferring mathematics to daily life, and concluded that model eliciting activities positively contributed to the idea of transferring mathematics to daily life and providing ideas about how to use mathematics in daily life. Verschaffel, De Corte, Lasure, et al. (1999) applied the model eliciting activities to the experimental group in order to increase the competence of 5 th grade students in solving mathematical application problems and obtained a significant increase in the proficiency levels of the students who took lessons with these activities. In addition, the persistence of students' attitudes, beliefs and achievements were significantly higher than the control group. Through the discussion environment presented by model eliciting activities, students develop mathematical language usage and collaborative learning environment through communication skills (Doruk, 2014). Beliefs in mathematics and problem solving change positively in the learning environment presented by the modeling perspective (Kal, 2013).

Modeling perspective and model eliciting activities enable students to develop positive attitudes and beliefs in the use of mathematical language, mathematics course and problem solving and improve their communication skills (Nuraina, 2018). It also ensures that they are academically successful and that the knowledge they have acquired in this field is permanent (Kandemir, 2011; Sagirli, 2010; Samsuriadi, 2019). Although the curriculum (MoNE, 2017b) aims to gain many skills that are aimed to gain, mathematical modeling or modeling perspective is not given sufficient level in the curriculum (Bilen $\&$ Ciltas, 2015; Rind \& Mughal, 2020). The reason for this is a separate research topic, but it may be related to the studies conducted in our country. The studies conducted in our country are limited to theoretical (Tekin Dede \& Bukova Güzel, 2013, 2014)or high school students (Hidiroglu, Tekin Dede, Kula, \& Bukova Güzel, 2014; Sagirli, 2010) and teacher candidates (Altun, Memnun, \& Yazgan, 2007; Deniz \& Akgün, 2016; Kertil, 2008). Although there are studies at primary and secondary level (Disbudak, 2014; Yildirim \& Isik, 2015; Nufus, 2020), it can be said that the existing studies are deprived of an effort to integrate mathematical modeling into existing mathematics teaching in school system, and to be suitable for acquisitions of lesson and grade level. When such an effort is made, it is observed that there are problems about whether the activities used in the research have the qualities of mathematical modeling. This study is the result of our desire to integrate mathematical modeling into the existing school system. We aim to analyze the contribution of the use of these activities to mathematics education by bringing modeling activities parallel to the acquisitions of lesson and supporting the current education.

In this study, the activities prepared in parallel with the class-level acquisition and appropriate to the modeling perspective are introduced to the literature, and it is expected to give an idea about how these activities will affect the success of the students in multiple choice tests. We bring a proposal to integrate mathematical modeling into schools with its application form. In addition, it is thought that the students' thoughts about the activity will contribute to the evaluation of the results on the current study about how these ideas affect the success of the multiple-choice test. 
Therefore, in this study, it is aimed to examine the effect of model eliciting activities on the achievement of mathematics lesson of $7^{\text {th }}$ grade students and their opinions about these activities. In order to achieve this aim, the following questions are sought.

1. What effect does teach with model eliciting activities have on students' academic achievement in standard achievement tests?.

2. What are the views of students for each activity?

3. How did the students' views on activities change during the implementation process?

4. What are the students' views on all activities ?.

\section{RESEARCH METHOD}

In this study, mixed research model was used as a model and explanatory sequential mixed method design was selected as a model in order to examine the effect of model eliciting activities on the success of students in mathematics lesson and to determine the reasons behind the success to support qualitatively the data obtained. The quantitative part of the research is a quasi-experimental study with pre-test post-test control group and the qualitative part is a case study.

The mixed research model was chosen because it is a model that allows the use of quantitative and qualitative research methods in a complementary manner to the current situation (Buyukozturk, Cakmak, Akgun, Karadeniz, \& Demirel, 2014). In studies involving intervention in a group, exploratory sequential design was chosen reason why it was one of the best patterns in explaining quantitative data (Creswell \& Plano Clark, 2014). In cases where random assignment cannot be made to the existing groups, the appropriate experimental method for quantitative research is the quasi-experimental method, which is why this study was chosen (Schumacher \& Mcmillan, 2006). The case study that allows the study of a phenomenon within its own reality and environment was chosen for the qualitative part of the study (Yıldırım \& Şimşek, 2013).

\subsection{Working Groups}

In the study, 7 th grade students of a secondary school participated in the Western Black Sea. The total number of students participating in the study is 47 and 23 are experimental (7 / B) and 24 are control group (7 / A). 12 of the experimental group were male and 11 of them were female, while 12 of the control group were female and 12 of them were male. Purposeful sampling and student selection were made for semi-structured interview. When selecting these students; they were selected according to the criteria of being at different success levels and being volunteer.

\subsection{Data Collection Tools}

In the quantitative part of the study, as a data collection tool, standardized mathematics test consisting questions of Level Determination Exam (LDE) questions, scholarship exam and Math textbooks were used. The specification table was used in the creation of this test. An expert academician and three teachers were asked whether they measured the behaviors to be measured. It is aimed to ensure the validity of the scope based on asking at least one question for each acquisition of specification table. In order to ensure the reliability of the scoring of the multiple-choice test, the scores obtained by the answer key were calculated over 100 .

The pilot application of the 28-item multiple-choice standard mathematics test was carried out with the permission of 74 students in the 7 th grade of another school. The item difficulty index and item discrimination index of the test items were calculated. According to Buyukozturk et al. (2014), items with an index value of 0,30 and above can be kept in the test without correction, therefore the cut-off point is accepted as 0,30. 7 test items with a index of discrimination less than 0.30 were excluded from the test. There was no deterioration in the scope validity due to at least one question per acquisition. As a result of these processes, the internal consistency coefficient of the test was calculated by Kuder Richardson formula and the $\mathrm{kr}-20$ value was found to be 0.84 . According to (Buyukozturk et al., 2014), it can be stated that the reliability of the test is high.

In the qualitative part of the study, data were collected through student opinion form, observation form and interview questions for the activity prepared by taking expert opinion. After these forms were prepared by taking expert opinion, it was piloted with 2 students from different schools. The students 'opinion (thought) form for the activity was given to the students after each activity in order to get the students' opinions as a written document. The observation form was used to record the experiences of the students during the implementation of the activities. Following the completion of the activities, semi-structured interviews were conducted with the selected students and these interviews were recorded with voice recorder.

\subsection{Model Eliciting Activities}

This study is the article of the thesis with the same title. Detailed information about model eliciting activities is available in the thesis of first author and is accessible (Karabork, 2016). This section provides the most general information about the events. Each activity consists of two parts. The first part includes the warm-up questions, which are the preparation of the modeling problem of the second part, which is related to real life, of the modeling activity of the students. Warm-up questions serve as a bridge between acquisitions (specific goals) and real-life problems. "Soccer Ball Activity" and "Smart Shadow Activity" (Lesh \& Doerr, 2003)were adapted from the literature. Unlike the original ones in the literature, the warm-up questions were adapted to serve the acquisition, and the related acquisition of the activities were tried to be brought to the forefront. "Land surveying activity", "decorative art activity" and "3D printer activity" were developed by the researchers. It was taken to expert opinion about whether these activities are in accordance with the principles. The topics that these activities are related to are as follows; "Soccer ball activity" polygons, "Smart shadow activity" rectangles, "Terrain measurement activity" area, "Decoration art activity" transformational geometry and "three-dimensional printer activity" is related to three-dimensional appearance.

\subsection{Data Collection and Application Process}

Before starting the study, the students in the school where the research will be conducted were informed that participation was voluntary. In the selected class, 23 out of 26 students volunteered to participate, whereas in the other classes this number was lower. Therefore, the class with the high number of volunteers was chosen as the experimental group. The study did not interfere with the way of the teachers taught. The students continued their courses in order to follow the normal course schedules. The intervention was in the form of the implementation of model eliciting activities in addition to 
normal teaching. For this reason, the activities were conducted in elective courses that were determined outside the mathematics class and where the class was appropriate.

During the implementation of the activities, the students were divided into three groups which were heterogeneous in terms of gender and achievement. The activities lasted 2 hours without a break. In the first part, students are given 10-15 minutes to think about the problems in the activities. Afterwards, they completed these tasks with group work by enabling them to work together with their friends. During the group work, they were asked to try to convince each other of the solutions brought in order to increase the use of mathematical language and to ensure that the explanations were based, and if they were convinced, they would sign the solution sheet of their friend otherwise they would not sign.

The small group discussion lasted 45 minutes. After this stage, the class discussion was started, and each group was asked to defend the solution by presenting it on the board. The presentations lasted 30 minutes. The solution, which was approved by all or the majority of the group, was presented to the class by the representative who selected within the group. During the presentations, it was ensured that other groups contributed to the solution of the group with criticism. Positive and negative thoughts were noted on the board in order to realize the strengths and weaknesses of the ideas presented during the discussion. As a result of this, the students had the opportunity to eliminate the deficiencies in their solutions, corrected the deficiencies and presented them to the class again and opened them for discussion. This process continued until the students were convinced of the adequacy of the solutions that they found. During the discussions, the researcher (teacher) insisted on the fact that the ideas put forward were based on evidence, but he contributed to the discussions by asking questions at important points, did not intervene to the students, and did not answer the questions himself.

Since the basic knowledge is necessary for the implementation of the activities, model eliciting activities were started after the first two acquisitions were processed in the course. During the implementation phase of the activities, how the students met the activities, what they did to overcome the problem they faced, what ways they tried to solve the problem encountered, the processes of testing the solutions they developed, the processes of renewing the solution or developing the processes were collected by the researcher by taking notes.

At the end of each activity, the opinions of all students about the activity were gathered with the opinion form. While the opinions of the students about each activity were taken, they were asked what they thought about the activity and the difference of the course with the other courses. In addition, in order to evaluate the activities from the eyes of the students, questions were asked to determine the suitability of the principles in table 1. Also, students were asked questions about whether the activities were related to the subjects in the lessons, how they were related, how the activities would benefit the students and how their experiences were seen from their own eyes.

The implementation of the activities lasted for three weeks and semi-structured interviews were conducted to get the students' opinions about the whole application. What were the characteristics of the course covered by interviews, model eliciting activities, what they could do even if the context of the activity was not of interest in daily life, and the effect of the activities on their success were asked? In addition, questions asked students about how their thoughts changed during the whole implementation process, which activity attracted their most attention and why they attracted their attention, what they thought about the activity, which they were the best and whether such activities should take place in mathematics classes. The process ended with the application of the final test.

\subsection{Data Analysis}

Pretest-posttest results were analyzed in order to test whether the control and experimental groups were statistically comparable. In order to decide which tests will be used in the analysis of the test results, the normality of the data and whether the variances were equal were tested. The results of the tests were reported under the title of findings. According to these results, it was seen that the data were distributed normally, and the variances were homogeneous, but there was a significant, not statistically, difference between the pre-test scores between the groups. The covariance analysis was used in order to control this difference which is thought to be the result of the current success of the classes and to better observe the change obtained as a result of experimental intervention between the two groups.

In qualitative data analysis, the documents obtained with qualitative data collection tools were analyzed by content analysis. The expressions obtained by content analysis were collected under themes within the framework of certain coding. The students were examined within the framework of the themes formed by the findings obtained from the observation form and observation form and the themes were expanded where necessary. Themes obtained by qualitative method have been made easier to interpret by converting them into quantitative data with the frequency of use of the students.

\section{RESULTS AND DISCUSSION}

In this section, there are quantitative results of working under the first title. Data collected through student opinion forms at the end of each activity and the change in the process are given under the relevant headings. In the last subtitle, the data regarding the interviews with the students are shown at the end of the intervention. Codes and themes for qualitative data are presented under the relevant titles.

\subsection{Effect of model eliciting activities on academic achievement}

The first sub questions of study related to achievement on multiple choice test result of students who deal with model eliciting activities. Firstly, to determine which kind of analysis method that use either parametric or non-parametric, homogeneity of variance and normality of the data should be tested. Findings related to the normality test are as in Table 2.

Table 2. Result of normality test for pre-posttest

\begin{tabular}{lccccccc} 
& Groups & \multicolumn{3}{c}{ Kolmogorov-Smirnov } & \multicolumn{3}{c}{ Shapiro-Wilk } \\
& & Statistic & df & p & Statistic & df & p \\
\hline Pre-test & Experiment & 0.104 & 23 & 0.200 & 0.965 & 23 & 0.565 \\
& Control & 0.144 & 24 & 0.200 & 0.951 & 24 & 0.285 \\
Post-test & Experiment & 0.105 & 23 & 0.200 & 0.962 & 3 & 0.532 \\
& Control & 0.091 & 24 & 0.200 & 0.951 & 4 & 0.285 \\
\hline
\end{tabular}

The data obtained from groups were reached as the result of normal distribution in both groups, $[\mathrm{p}=0.200, \mathrm{p}>.05]$ 
according to table 2. The Levene test was conducted for the homogeneity of the variances as shown in Table 3.

Table 3. Result of pre-posttest for Levene test

\begin{tabular}{crr} 
Levene test & $F$ & $P$ \\
\hline Pre-test & 2.959 & 0.920 \\
Post-test & 0.000 & 0.992 \\
\hline
\end{tabular}

These values were found to be homogeneous both pre-test (p $=.920>.05)$ and post-test $(p=.992>.05)$. It was decided to use $t$ test for independent samples in order to evaluate pre-test results at the end of these findings. The findings of t-test are found as presented in table 4 .

Table 4. Result of independent samples t-test for pre-test

\begin{tabular}{cccccccc}
\hline & Groups & $\mathrm{N}$ & $\overline{\mathbf{X}}$ & $\mathrm{Sd}$ & $\mathrm{t}$ & $\mathrm{df}$ & $\mathrm{p}$ \\
\hline \multirow{3}{*}{ Pre-test } & Experiment & 23 & 42.65 & 4.87 & 0.636 & 45 & 0.528 \\
& Control & 24 & 46.82 & 9.71 & & & \\
\hline
\end{tabular}

In Table 4, on the results of independent samples t-test revealed not significance difference between groups in pre-test, $[\mathrm{t}=0.6336, \mathrm{p}>.05, \overline{\mathbf{x}} \mathrm{E}=42.65, \overline{\mathbf{x}} \mathrm{C}=46.82]$. Although there was no statistically significant difference in the pretest success of the groups, taking the pretest results as control variables, the posttest results were analyzed by covariance analysis in order to control the effect of the difference of the pre-test means. In order to perform the covariance analysis, except for the normal distribution of the data and the homogeneity of the variances, linearity assumption for relation between the controlled variable and the dependent variable were checked using the linear scatter plot. Finally, the group*pre-test interaction was checked for the assumption of equality of regression slopes. As a result, it was found that the common effect was meaningless, $(F(1,43)$ $=.78, \mathrm{p}>.05$ ). This finding indicates that the slopes of the regression lines are equal for the predictions of the posttest scores of the students in the two groups, depending on the pre-test. The means and the corrected means of the post-test scores corrected according to pre-test results presented in Table 5 .

Table 5. The means and the readjusted means of the

\begin{tabular}{cccc}
\multicolumn{4}{c}{ post-test scores } \\
Group & N & Means & Readjusted means \\
\hline Experiment & 23 & 63.98 & 65.32 \\
Control & 24 & 52.98 & 51.69 \\
\hline
\end{tabular}

When the adjusted mean scores and the uncorrected average scores were examined, it was observed that the difference in points favoring the experimental group was further increased. The mean score of the experimental group increased from $\overline{\mathbf{X}}=63.98$ to $\overline{\mathbf{X}}=65.32$, while the average score of the control group decreased from $\overline{\mathbf{X}}=52.98$ to $\overline{\mathbf{X}}=51.69$. The results of the ANCOVA as seen in Table 6.

Table 6. Result of ANCOVA for readjusted post-test score based on pre-test score

Dependent variable: Post-test

\begin{tabular}{lllllll}
$\begin{array}{l}\text { Source of } \\
\text { Variance }\end{array}$ & $\begin{array}{l}\text { Sum } \\
\text { Squares }\end{array}$ & of & $\begin{array}{l}\text { Mean } \\
\text { square }\end{array}$ & F & p & $\begin{array}{l}\text { Partial } \\
\text { n2 }\end{array}$ \\
\hline Intercept & 8398.691 & 1 & 8398.691 & 57.514 & 0,000 & 0,567 \\
Group & 2162.632 & 1 & 2162.632 & 14.810 & 0,000 & 0,252 \\
Pre-test & 9045.029 & 1 & 9045.029 & 61.940 & 0,000 & 0,585 \\
Error & 6425.234 & 44 & 146.028 & & & \\
Total & 176959.339 & 47 & & & & \\
\hline
\end{tabular}

A significant difference was found between the post-test mean scores corrected for the results of the covariance analysis in favor of the test group, $[\mathrm{F}(1,44)=61.94, \mathrm{p}<0.05, \mathrm{\eta} 2=0.25]$. $25 \%$ of the change in the academic achievement scores of the group's successes is explained by group membership. The impact of group membership on students' academic achievement scores is great. To determine how intra-group success and the effectiveness of teaching in each group changed, the normality test was used to determine whether the difference between pre-posttest measurements from each group was normally distributed.

Table 7. Result of normality test of difference between pre-posttest measurements

\begin{tabular}{ccccccc}
\multirow{2}{*}{ Groups } & \multicolumn{3}{c}{ Kolmogorov-Smirnov } & \multicolumn{3}{c}{ Shapiro-Wilk } \\
& Statistic & Sd & $\mathrm{p}$ & Statistic & Sd & $\mathrm{p}$ \\
\hline Experiment & 0.133 & 23 & 0.200 & 0.949 & 23 & 0.282 \\
Control & 0.130 & 24 & 0.200 & 0.955 & 24 & 0.371 \\
\hline
\end{tabular}

As shown in Table 7 , the normality test results of the differences between the measurements obtained from each study groups difference between pre-posttests was found not significance, $(p=0,200,>.05)$. Consequently, the differences from pre-posttest of each group were distributed as the normal.

Table 8. Paired samples t-test result of control group

\begin{tabular}{ccccccc} 
Group & Test & $\overline{\mathbf{x}}$ & $\mathrm{N}$ & $\mathrm{Sd}$ & $\mathrm{t}$ & $\mathrm{p}$ \\
\hline Control & Pre-test & 46.83 & 24 & 24.87 & 1.988 & 0.059 \\
& Post-test & 52.98 & 24 & 19.22 & & \\
\hline
\end{tabular}

Table 8 shows the result of paired samples t-test the difference between the pre-test and post-test averages of the control group was not significant between the pre-test and post-test success of the control group $[\mathrm{t}=-1,988, \mathrm{p}=$ 0,059, >.05].

Table 9. Paired samples t-test result of experiment group

\begin{tabular}{ccccccc} 
Group & Test & $\overline{\mathbf{x}}$ & $\mathrm{N}$ & $\mathrm{Sd}$ & $\mathrm{t}$ & $\mathrm{p}$ \\
\hline Experiment & Pre-test & 42.65 & 23 & 19.71 & -7.352 & \\
& Post-test & 63.98 & 23 & 17.81 & & 0.000 \\
\hline
\end{tabular}

There was a positively significant difference between the pre-test scores and post-test scores of the experimental group [ $\mathrm{t}$ $=-7,352, \mathrm{p}=.000, \mathrm{p}<.05]$. The effect size was calculated as $\mathrm{n}^{2}=$ 0,710 . According to this finding, it can be stated that applying the modeling activity as a variable has a great influence on the mathematics success of 7 th grade students. The model eliciting activity variable explains Seventy-one percent of the change in the achievement of the mathematics success of the students.

\subsection{Student views on model eliciting activities}

In this section, students' opinions on each activity are presented together with the findings obtained from observation forms and students' opinion form about related activity. When the expressions have quoted from the student, the first letter of the student's name is used and if students have same first letter, the number used after the letter.

While the students were working on the activities, they generally tried to do their first solutions on the activity papers. After they have thought that this way not reach solution, they tried new ways and to make decisions were tried by calculating 
to whether these ways produce solutions or not. When doing these calculations, they used telephone, calculator, etc. Also, the numbers have rounded off in order to make calculations easily with the utilization of technological tools. When they first met with the problem situation, the students expressed their thoughts about the problem as difficult to understand, not a solvable, and not about the mathematics. With the help of the group and class discussions students proceed to own solution. When the students not proceeded in activity, they return the first thought or solution about activity. However, they had any idea to solution, they were quite willing and actively try this idea that whether were reached solution or not. At the beginning of the other activities, students who gave similar responses like first activity. But they have moved off their negative thoughts more quickly than first activity, due to thought that "if we struggle and think about how solve this problem, we will found anyway".

Some of the answers given by the students to question of "What do you think about the event, how does it differ from the activities you did in the other lessons?" are as below

A: On the one hand it is good and on the other hand it is boring and we constantly solve problems in other courses. The good thing is that we learn by doing it effectively and it becomes more permanent and on the other hand I cannot continue the activity if we cannot find anything

B2: I liked the activity but it was difficult and thought-provoking, but it was still nice comparing the normal lesson that we only solve the questions, in this activity we find a solution with our own efforts

B1: I find this activity different from other activities, it feels like doing experiment

Ş1: It was different but very boring, also the course is different because the use of electronic tools and operations such as cutting, attaching

A: I did not like the activity but it made me go further in the subject of area and the environment

F1: it was difficult, in this lesson we will find something ourselves normally teachers tell

E1: It was nice but difficult because it required a lot of work and effort. If all courses were like this, my performance could increase because my knowledge was reinforced.

E2: It was a bit challenging and hard, but it was nice. The difference from the other activities was that we made too many drawings and defended our actions against our friends.

After these frequently repeated and interrelated words are identified in the answers given by the students, these words are gathered under the codes and themes which are the same as in table 10. Although the form applied to students consists of open-ended questions, the first question gives long answers, while the other questions are generally short answers. This has affected the way data are presented. The first question with long answers is presented separately (difference theme), other questions are presented separately.

Table 10. Themes and codes gathered from students' opinions forms

\begin{tabular}{|c|c|}
\hline Themes & Codes \\
\hline Difference & $\begin{array}{l}\text { Difficult-boring, Nice-amusing, Challenging, Active } \\
\text { participation, Educative-instructive, Group work, Like } \\
\text { experiment }\end{array}$ \\
\hline Principles & $\begin{array}{l}\text { Reality, Producing original solution, Generalizability of } \\
\text { solution }\end{array}$ \\
\hline $\begin{array}{l}\text { Association } \\
\text { capacity }\end{array}$ & $\begin{array}{l}\text { Related student's daily life interest, Related to math } \\
\text { lesson subject }\end{array}$ \\
\hline
\end{tabular}

Usability Provide benefit

As shown in table 11 , model eliciting activities come to the forefront with educative-instructive, difficult-boring, nice-amusing and challenging characteristics. First two activities are football and smart shadow activity, 39.13\% of students found these activities difficult and boring. Also 13.04\% in land measuring activity and $17.39 \%$ in adornment activity, there was a decrease compared to the first activities, while the last activity of the 3D printer activity, 34.78\% of students stated that it is difficult and boring. On the other hand, $30.43 \%$ of the students in first two activities, $26.09 \%$ of the land measuring activity, $56.52 \%$ of the adornment activity and $47.83 \%$ of the $3 \mathrm{D}$ printer activity were described as nice and amusing. Percentages given in the table are the ratio between the number of individuals using that expression and number of all student in experiment group $(n=23)$. Since a person uses more than one expression, the total number is more than the number of class members.

Table 11. Difference theme of model eliciting activities to mathematics lesson activities

\begin{tabular}{|c|c|c|c|c|c|c|c|c|c|c|}
\hline \multirow[t]{3}{*}{ Code } & \multicolumn{10}{|c|}{ Activity } \\
\hline & \multicolumn{2}{|c|}{ Football } & \multicolumn{2}{|c|}{$\begin{array}{l}\text { Smart } \\
\text { shadow }\end{array}$} & \multicolumn{2}{|c|}{$\begin{array}{c}\text { Land } \\
\text { measuring }\end{array}$} & \multicolumn{2}{|c|}{ Adornment } & \multicolumn{2}{|c|}{ 3D Writer } \\
\hline & $N$ & $\%$ & $\mathrm{~N}$ & $\%$ & $\mathrm{~N}$ & $\%$ & $\mathrm{~N}$ & $\%$ & $\mathrm{~N}$ & $\%$ \\
\hline Difficult-boring & 9 & 39.13 & 9 & 39.13 & 3 & 13.04 & 4 & 17.39 & 8 & 34.78 \\
\hline Nice-amusing & 7 & 30.43 & 7 & 30.43 & 6 & 26.09 & 13 & 56.52 & 11 & 47.83 \\
\hline Challenging & 3 & 13.04 & 2 & 8.70 & 2 & 8.70 & 2 & 8.70 & - & - \\
\hline $\begin{array}{c}\text { Educative-instr } \\
\text { uctive }\end{array}$ & 6 & 26.09 & 2 & 8.70 & 8 & 34.78 & 4 & 17.39 & 3 & 21.74 \\
\hline $\begin{array}{c}\text { Active } \\
\text { participation }\end{array}$ & - & - & & - & 5 & 21.74 & 7 & 30.43 & 5 & 21.74 \\
\hline Group work & 5 & 21.74 & - & - & - & - & 5 & 21.74 & 4 & 17.39 \\
\hline $\begin{array}{c}\text { Like } \\
\text { experiment }\end{array}$ & - & - & 7 & 30.43 & - & - & - & - & - & - \\
\hline
\end{tabular}

The thought on these activities require intensive efforts is expressed by $13.04 \%$ of the students in the football activity, $8.7 \%$ of students in the smart shadow, land measuring and adornment activities. They did not comment on 3D printer activity in this direction. In addition, the ratio of the opinions that the activities are educative and instructive is $26.09 \%$ in football activity, $8.7 \%$ in smart shadow activity, $34.78 \%$ in land measuring activity, $17.39 \%$ in adornment activity and $21.74 \%$ in $3 \mathrm{D}$ printer activity.

Considering the classroom environment offered to students by activities $21.74 \%$ of the students stated that the group work was different from other activities in football and adornment activities and $17.39 \%$ of them in $3 \mathrm{D}$ printer activity. In addition, $21.74 \%$ of the students stated that they were active in the land measuring and 3D printer activities, while $30.43 \%$ stated that they were actively participating in the adornment activity.

With the other questions asked in the questionnaire were aimed both to determine the reasons behind the success of the students and to evaluate appropriateness of the activities according to the principles via student's views. Since other modeling principles are provided through observations, it is also not included in the student opinion form. For this reason, questions were asked about the relevance of activities to real life, whether allows generalized and original solutions. It was also 
questioned whether the context of the activity was related to the math lesson's subject, it was a matter of interest in daily life and the activities provide a benefit. The answers given to these questions were presented on the tables in the context of each activity.

Table 12. Other views of student about football activity

\begin{tabular}{|c|c|c|c|c|c|c|c|}
\hline Theme & Code & & Yes & & No & & No idea \\
\hline & & $\mathrm{N}$ & (\%) & $\mathrm{N}$ & (\%) & $\mathrm{N}$ & (\%) \\
\hline \multirow[t]{3}{*}{ Principles } & Reality & 16 & 60.87 & 4 & 7.39 & 3 & 13.04 \\
\hline & $\begin{array}{l}\text { Producing original } \\
\text { solution }\end{array}$ & 17 & 73.91 & 4 & 7.39 & 2 & 8.70 \\
\hline & $\begin{array}{l}\text { Generalizability } \\
\text { of solution }\end{array}$ & 10 & 43.48 & 11 & 47.82 & 2 & 8.70 \\
\hline \multirow[t]{2}{*}{$\begin{array}{c}\text { Association } \\
\text { capacity }\end{array}$} & $\begin{array}{l}\text { Related student's } \\
\text { daily life interest }\end{array}$ & 6 & 26.09 & 17 & 73.91 & - & - \\
\hline & $\begin{array}{l}\text { Related to math } \\
\text { lesson subject }\end{array}$ & 21 & 91.30 & 2 & 8.70 & - & - \\
\hline Usability & Provide benefit & 18 & 78.26 & 5 & 21.74 & - & - \\
\hline
\end{tabular}

With regard to football activity, $60.87 \%$ of the students think that the activity is involved the problem that they can face in daily life, while $73.91 \%$ think that they produce the solution to this problem as unique for them, $43.48 \%$ of students think about the solutions that can be generalized. $73.91 \%$ of students are not interested in the subject that the activity is related to in daily life. In addition, $91.30 \%$ of the students think that the activity is related to the subject, while $78.26 \%$ stated that the activity will be beneficial for them.

Table 13. Other views of student about Smart shadow activity

\begin{tabular}{|c|c|c|c|c|c|c|c|}
\hline \multirow[t]{2}{*}{ Theme } & \multirow[t]{2}{*}{ Code } & \multicolumn{2}{|c|}{ Yes } & \multicolumn{2}{|c|}{ No } & \multicolumn{2}{|c|}{ No idea } \\
\hline & & $\mathrm{N}$ & (\%) & $\mathrm{N}$ & (\%) & $\mathrm{N}$ & (\%) \\
\hline \multirow[t]{3}{*}{ Principles } & Reality & 14 & 60.87 & 9 & 39.13 & - & - \\
\hline & $\begin{array}{l}\text { Producing original } \\
\text { solution }\end{array}$ & 14 & 60.87 & 7 & 30.14 & 2 & 8.70 \\
\hline & $\begin{array}{c}\text { Generalizability of } \\
\text { solution }\end{array}$ & 14 & 60.87 & 9 & 39.13 & - & - \\
\hline \multirow[t]{2}{*}{$\begin{array}{c}\text { Association } \\
\text { capacity }\end{array}$} & $\begin{array}{l}\text { Related student's } \\
\text { daily life interest }\end{array}$ & 4 & 17.39 & 19 & 82.61 & - & - \\
\hline & $\begin{array}{l}\text { Related to math } \\
\text { lesson subject }\end{array}$ & 13 & 56.52 & 8 & 34.78 & 2 & 8.70 \\
\hline Usability & Provide benefit & 14 & 60.87 & 8 & 34.78 & 1 & 4.35 \\
\hline
\end{tabular}

Smart shadow activity is the most challenging activity for students to solve. Although the football activity was the first, students produced a solution with some difficulties. Smart shadow activity is the most difficult activity for produce a solution among presented activities. However, the \%60.87 of students thought about their solution as an original solution like the generalizability of the solution and the reality of the problem. The relation between these activities and the subject of mathematics lesson was expressed by \%56.52 of students, because of the nature of this activity, which is related to many subjects such as light and shadow, polygons with properties of edges, angles and diagonal. This is the lowest rate among all activities for relation to math lesson. Moreover, $82.61 \%$ of the students stated that such a subject does not interest in everyday life. As a result of the obtained solution's inadequacy, the beneficial thoughts provided by the activity decreased by $60.87 \%$ from the previous activity.

Table 14. Other views of student about Land measuring activity

\begin{tabular}{|c|c|c|c|c|c|c|c|}
\hline \multirow[t]{2}{*}{ Theme } & \multirow[t]{2}{*}{ Code } & \multirow{2}{*}{$\frac{\text { Yes }}{N}$} & \multicolumn{2}{|c|}{ No } & \multicolumn{3}{|c|}{ No idea } \\
\hline & & & (\%) & $\mathrm{N}$ & (\%) & $\mathrm{N}$ & (\%) \\
\hline \multirow[t]{3}{*}{ Principles } & Reality & 23 & 100 & - & - & - & \\
\hline & $\begin{array}{l}\text { Producing original } \\
\text { solution }\end{array}$ & 19 & 82.60 & 2 & 8.70 & 2 & 8.70 \\
\hline & $\begin{array}{c}\text { Generalizability of } \\
\text { solution }\end{array}$ & 21 & 91.30 & 1 & 4.35 & 1 & 4.35 \\
\hline \multirow[t]{2}{*}{$\begin{array}{l}\text { Association } \\
\text { capacity }\end{array}$} & $\begin{array}{l}\text { Related student's } \\
\text { daily life interest }\end{array}$ & 2 & 8.70 & 21 & 91.30 & - & \\
\hline & $\begin{array}{l}\text { Related to math } \\
\text { lesson subject }\end{array}$ & 22 & 95.65 & 1 & 4.35 & - & \\
\hline Usability & Provide benefit & 23 & 100 & - & & - & \\
\hline
\end{tabular}

As shown in Table 14, the reality and usefulness of the land measuring activity is expressed by $100 \%$ of the students. If land measuring activity was compared to previous events the perceptions of the students for originality and generality (respectively \%82.60 and \%91.30) of the solutions produced by themselves have increased. $95.65 \%$ of the students stated that the content of the activity was related to the mathematics course. Despite these facts, the proportion of students who are interested such a subject in daily life is \%8.70.

Table 15. Other views of student about Adornment activity

\begin{tabular}{|c|c|c|c|c|c|c|c|}
\hline \multirow[t]{2}{*}{ Theme } & \multirow[t]{2}{*}{ Code } & \multicolumn{2}{|c|}{ Yes } & \multicolumn{2}{|c|}{ No } & \multicolumn{2}{|c|}{ No idea } \\
\hline & & $N$ & (\%) & $N$ & (\%) & $\mathrm{N}$ & (\%) \\
\hline \multirow[t]{3}{*}{ Principles } & Reality & 21 & 91.30 & 2 & 8.70 & - & - \\
\hline & $\begin{array}{l}\text { Producing } \\
\text { original solution }\end{array}$ & 20 & 86.95 & 3 & 13.05 & - & - \\
\hline & $\begin{array}{c}\text { Generalizability } \\
\text { of solution }\end{array}$ & 20 & 86.95 & 2 & 8.70 & 1 & 4.35 \\
\hline \multirow[t]{2}{*}{$\begin{array}{l}\text { Association } \\
\text { capacity }\end{array}$} & $\begin{array}{l}\text { Related } \\
\text { student's daily } \\
\text { life interest }\end{array}$ & 12 & 52.17 & 11 & 47.83 & - & - \\
\hline & $\begin{array}{l}\text { Related to math } \\
\text { lesson subject }\end{array}$ & 22 & 95,65 & 1 & 4.35 & - & - \\
\hline Usability & Provide benefit & 23 & 100 & - & - & - & - \\
\hline
\end{tabular}

All students mentioned the Adornment activity as beneficial and $\% 91.30$ of students approved Adornment activity's reality. The generated solutions for Adornment problem were stated as original and generalizable by $\% 86.95$ of students. More than half of the students interested such a subject in daily life.

Table 16. Other views of student about 3D Writer activity

\begin{tabular}{lccccccc} 
Theme & Code & \multicolumn{2}{c}{ Yes } & \multicolumn{2}{c}{ No } & \multicolumn{2}{r}{ No idea } \\
& & $N$ & $(\%)$ & $N$ & $(\%)$ & $N$ & $(\%)$ \\
\hline Principles & Reality & 22 & 95,65 & 1 & 4.35 & - & - \\
& $\begin{array}{c}\text { Producing original } \\
\text { solution }\end{array}$ & 18 & 78,26 & 4 & 17.39 & 1 & 4.35 \\
& $\begin{array}{c}\text { Generalizability of } \\
\text { solution }\end{array}$ & 18 & 78,26 & 4 & 17.39 & 1 & 4.35 \\
Association & $\begin{array}{c}\text { Related student's } \\
\text { capacity }\end{array}$ & 8 & 34,78 & 1 & 65.22 & - & - \\
daily life interest & & & 5 & & &
\end{tabular}


Related to math $23 \quad 100 \quad-\quad-\quad-\quad$ -

lesson subject

Provide benefit

23

Usability

All students commented that the 3D Writer activity was beneficial and related to the mathematics course. In addition, $95.65 \%$ of the students stated that the activity was involved problem that could be met in real life. At the end of the $3 \mathrm{D}$ activity, the originality and generalization of the solution were mentioned by $78.26 \%$ of the students. Most of the students are not interested in everyday life, as the theme of your activity is the majority of previous activities.

\subsection{Exchange of other views on activities during the implementation process}

In this part of the study, we tried to present how thoughts about the activities applied during a unit changed. The findings of this research question are presented in two parts. In the first part, students' thoughts about the activities are given. As it is possible to see the change in these thoughts in Table 2, the table is not included in this title again. In the second part, the change of themes related to whether the modeling activities used in the research are appropriate with the modeling principles is summarized in graph 1 . In addition, the change in whether the ideas about the usefulness of the activities as well as whether the real-life issues that the activities are related to or not in the field of interest of the students are presented in the graph 1 .

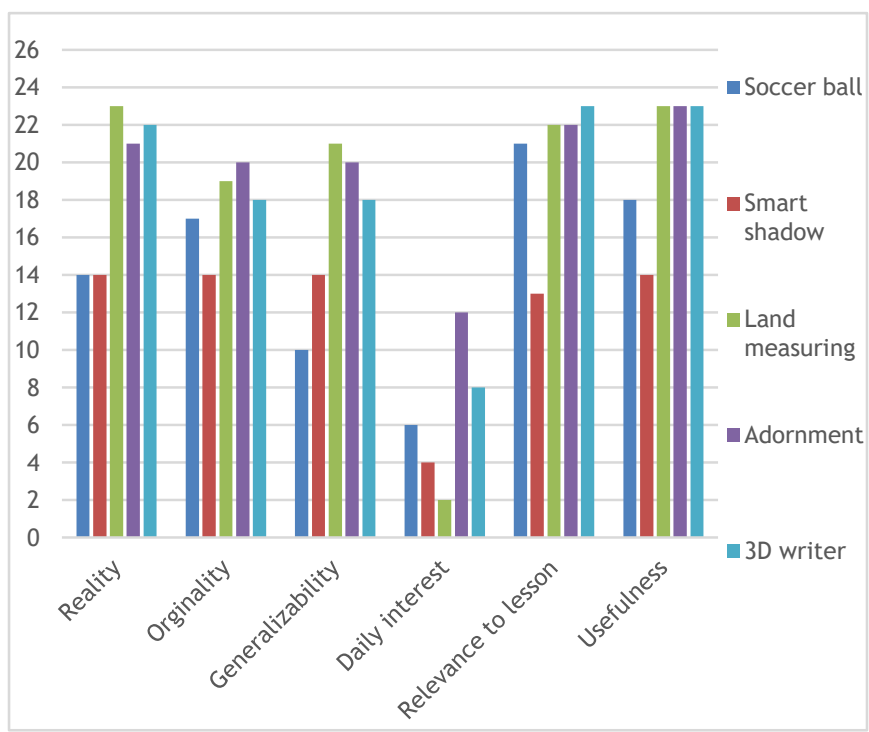

Graph 1. Exchange of other opinions for activity

When Table 2 is examined, it is observed that the students views about the difference of the activities from the tasks in the normal mathematics course show a positive increase but is not linear. While the thoughts that the activities were difficult and boring decreased from $39.13 \%$ to $13.04 \%$, the ideas that it was nice and fun increased from 30.43 to 56.52 . While active participation and group work did not come to the forefront in the first activities, it became a feature that attracted the attention of more students in the last activities. Thoughts about being Challenging is decreased after the first activity. Thoughts related to the characteristics of the activities to be educative and instructive did not follow a positive or negative trend, this characteristic is completely depending the activity.

When the graph 1 is examined, the reality of the activities, the originality of the solutions they have reached or used in solving the problem, the generalizability of the solutions is expressed by students. In addition, the relationship of the activities with the lesson and the ideas that these activities will benefit them tend to increase in a positive but not linear way.

\subsection{Students' thoughts about the overall activities (process)}

After the implementation was completed, semi-structured interviews were conducted with a total of 6 students, 4 girls and 2 boys, in order to get the students' opinions about the overall activities. The themes and codes obtained from these interviews are presented in table 16. Details of the results are mentioned below.

Table 17. Interview's themes and codes

\begin{tabular}{|c|c|c|c|c|}
\hline Theme & Sub-theme & Codes & \multicolumn{2}{|c|}{ Thoughts } \\
\hline & & & $(+)$ & $(-)$ \\
\hline & & & (\%) & $(\%)$ \\
\hline \multirow[t]{2}{*}{$\begin{array}{l}\text { Contribution to } \\
\text { mathematics } \\
\text { lesson }\end{array}$} & $\begin{array}{l}\text { Class } \\
\text { environment }\end{array}$ & $\begin{array}{c}\text { Challenging, } \\
\text { Educative-instructive, } \\
\text { nice-amusing }\end{array}$ & 83,33 & 16,67 \\
\hline & $\begin{array}{l}\text { Attitude and } \\
\text { success }\end{array}$ & $\begin{array}{c}\text { Because of nice-amusing, } \\
\text { interest, attention }\end{array}$ & 100 & - \\
\hline $\begin{array}{l}\text { Changing of } \\
\text { thoughts }\end{array}$ & - & $\begin{array}{c}\text { Solution come out, } \\
\text { confidence, uncomplete }\end{array}$ & 100 & - \\
\hline $\begin{array}{c}\text { Effect of daily } \\
\text { interest }\end{array}$ & - & Not affect, compulsion, & 33,33 & 66,67 \\
\hline
\end{tabular}

To get students' opinions about the use of such activities in the course "What would be the characteristics of this course if these activities were used in mathematics lessons?" was asked. Such a lesson is challenging for $16.67 \%$ of the students on the other hand it is a nice-fun and educative-instructive for $83.33 \%$ of the students. Actually, the activity's being challenging is a positive feature for us, but since we think it is negative for the student, we described this view as above. The students' answers to this question are as follows.

M1: We need to think more about the lessons that we use these activities because they involve serious questions

M2: illuminating, tutorial, be a fun lesson

Q1: More funny and tutorial lesson

A: It would be fun and we would even understood the subject better

In order to examine the effect of whether or not the subject is of interest to the student's participation in the activity and the production of a solution. "What did you do in activities related to topics that are not of interest to you? Explain if it makes it difficult for you to find a solution to the given problem" was asked. The fact that $66.67 \%$ of the students did not enter into the field of interest in the problem situation included in the activity made participation and solution production difficult, while $33.33 \%$ of the students stated that such a situation did not affect themselves. The students' answers to this question are below.

M1: Yes, it was a little hard because I did not have much interest in, and I did not know what to do.

$B$ : it is difficult to find solutions for activities that are not of our interest.

M2: I tried to solve it but I had a hard time because I had no 
idea

\section{Ş1: Although it is not my interest, I joined more}

"Does this type of activity contribute to your success in mathematics?" was asked in order to determine how activities affect their beliefs about their success. All of the students stated that such activities would contribute to their success in a positive way. When asked why their success will increase, the reason for contributing to lesson success is; $50 \%$ of students attributed the activities to be nice and fun activities, 33.3\% increased their interest in the lesson and $16.67 \%$ increased their attention. The answers to this question are as follows.

M2: I think it allows because such activities are more fun for this reason, more connects us to the lesson

A: Yes, because we do things about math because we do it in a fun way, sometimes we get bored in normal lessons, then we are reluctant, but we are willing to do these activities.

M3: We had to make a lot of effort and concentration to do the activities and this increased our attention.

" Please explain whether there was a change in your thoughts about the activities during the implementation process." All of the students stated that their thoughts changed positively and they had a different experience in each activity. The reason for the change in this direction is that according to $66.67 \%$ of the students think that the solution will surely come out. According to $33.33 \%$ of the thoughts that increase their confidence over time. Students' answers to this question are as below.

M1: Of course, there was a change. Every activity was a different experience for me. At first, I thought that activity was difficult and absurd. I thought that there would be a solution at the end of this activity and each one.

B: I did not know what to do at first. Later, I thought at the beginning of each activity that I thought I knew that a solution would come out in the following events.

M2: Yes, I felt different things in each activity, all of them were nice, I had difficulty in all of them, but I said that overcoming this difficulty increased my confidence in each activity a little more.

"Should such activities take place in mathematics classes? If yes, how should it be implemented?" All students answered yes to the first question. The second one is replied by $50 \%$ of the students as should be applied after each activity, $16.67 \%$ stated as should be done occasionally and $33.33 \%$ stated as should be done as a group. The answers to this question are as follows.

M1: I think it should take place, it sometimes takes place

M2: Yes, there should be an activity of each topic should be implemented when the topic is over.

M1: It should take place after the application as a group

M3: Yes, there should be more group discussions

In the question where the most remarkable activity is asked, decorative art activity and land measurement activity seems to be the most remarkable activity according to $33.33 \%$ of the students. Three-dimensional printer activity attracted the attention of $16.67 \%$ of students and shadow activity attracted the attention of $16.67 \%$ of students. Students' answers to this question are as below.

$B$ : I liked the fact that we were drawing in $3 D$ writer activity, especially since I could draw.

M2: It was a land measuring activity because it was fun to find different solutions and discuss them

A: It was an adornment activity, and I'm already interested in decoration in daily life.

Students were asked "what they thought of their best activity" At the beginning of the activity, $83.33 \%$ of the students thought that they could not, and $16.67 \%$ were surprised. His thoughts changed as he struggled in the later stages of the event or received support from his friends. All of the students expressed this situation by saying "I can do it ". The students' answers to this question are as follows.

M1: At first, I thought I would not, but when I tried, I realized I could.

A: I thought I wouldn't do it and I try something then I could.

M3: Even though I didn't think I was going to do it at first, I realized that I could do it with the support of group work and friends.

\section{CONCLUSION}

Multiple choice academic achievement tests are one of the common assessment tools we use to evaluate students. According to the results obtained in this study, the use of model eliciting activities as a supportive method contributes to students' academic achievement test in a statistically significant positive way. There are studies supporting this finding (Blum, 1993; Boaler, 2001; English, 2004; Sagirli, Kirmaci, \& Bulut, 2010; Yildirim \& Isik, 2015).

While the study was conducted, an intensive effort was made to minimize the effects of negative factors such as students' level (activities prepared according to the level of students), classroom environment and other factors that might affect the study. Actually, Disbudak (2014) stated that due to such factors, model eliciting activities could not show sufficient effect on students' achievements. We believe that it is important to ensure attendance and participation, which is one of the factors that can be influenced by the end of the semester and which may affect the study. Although we do not make any extra effort to ensure the attendance and participation of the students, the activities and practices applied in this regard will provide this. Students' thoughts on activities support this view.

Since model building activities include authentic problems, students experience uncertainty in understanding the problem and taking action towards a solution when they first encounter such activities. But when they think about the problem, they offer a solution to the problem based on their own experiences and they work intensively and actively to try this way. Other researchers (Karali \& Durmus, 2015; Sagirli et al., 2010; Verschaffel, De Corte, \& Vierstraete, 1999) have similar responses to the students participating in this study.

Connecting the success of the students to the content of the activities is to ignore the learning environment provided by the activity to the students. As Doruk (2014) states, model eliciting activities are carried out in a group work, which paves the way for the development of students' communication skills. Students' expressing themselves both in their own groups and in class discussions and having arguments to support their ideas while expressing them increase their self-confidence in communication and improve their ability to use mathematical language (Biembengut, 2007). The fact that students use persuasion methods based on numerical data and concrete material representation to convince each other during the implementation of the activities overlaps with these expressions.

During the group work, the students both supported and criticized each other's ideas. The intellectual support offered to each other by the students is both internal and external motivation for the student who put forward the idea (Stipek, 2002). This desire enables the student to participate more effectively in the problem-solving process. Attitudes of the 
students attending this course change in a positive way (Bilen $\&$ Ciltas, 2015). In addition, self-efficacy perceptions and self-regulation skills are also changing positively (Sagirli et al., 2010). Although we did not use quantitative tools to measure these features in this study, the qualitative data obtained were to support the results of other studies.

As a result of the examination of the students 'views on the appropriateness of the activities to the principles it should bear, it reveals that there is a change in the students' thinking about the quality of the solutions produced in mathematics course. The students' thoughts about the solutions they produce in the activities changed from the idea that there is a single solution or a single result to more than one solution. This finding confirms Zawojewski and Lesh (2003) opinion about the authenticity of the solutions.

As a result of the process, it is a thought that students see the challenging, educational and instructive, entertaining and beautiful features of the activities as the features that make the activities different and as a supporter to the mathematics lesson. Especially the challenging part of the events was overcome with experience and friend support. Although the teachers have doubts about this subject (Blum \& Leiss, 2005; Deniz \& Akgün, 2016; Karali \& Durmus, 2015; Verschaffel, De Corte, \& Vierstraete, 1999), the presented data in current study shows that this negativity will disappear in the process with the idea that the students will try and find a solution.

In the literature (Hidiroglu et al., 2014; Karali \& Durmus, 2015; Tekin Dede \& Bukova Güzel, 2013, 2014), it is important to choose the activities from the interests of students in their daily lives, especially in the studies where teacher opinions are taken. However, our observations here on this issue are only the threshold that this situation is effective at starting the activity, this threshold friend support etc. If it is exceeded, it reveals the importance of being a real situation rather than students' interests in daily life.

\section{ACKNOWLEDGEMENTS}

In this study, model eliciting activities prepared in parallel with the acquisitions throughout a unit at a certain class level is one of the contributions to the literature. Activities in the literature are activities independent of acquisitions or not associated with acquisitions. It is for this reason that the appropriateness of these activities to the modeling principles is also evaluated from the eyes of the students. Investigation of how and to what extent the long-term implementation of the activities affects the classroom culture, students' beliefs and attitudes towards the lesson and themselves is thought to enable these activities to be implemented in schools.

In many real-life applications of mathematical modeling, real-life situations need to be generalized by formulating. In this study, the models put forward by the students could not go beyond table or verbal solution expressions. Considering the students' experiences at school, the students were not forced to do so. Whether modeling activities are used to develop formulating skills is an issue that needs to be explored.

As a result of this study, model eliciting activities increase students' academic success. In addition to the positive change in attitude and belief in the learning environment that occurred during the implementation of the activities, the development of skills such as communication skills and the use of mathematical language led to an increase in academic achievement. Allowing the development of these skills in the learning environment in the use of model eliciting activities in the lessons is seen as a matter that the practitioners should pay attention to.

\section{REFERENCES}

Altun, M., Memnun, D. S., \& Yazgan, Y. (2007). The Primary School Teacher Trainees' Skills and Opinions on Solving Non-Routine Mathematical Problems. Elementary Education Online, 6(1), 113-126.

Bardini, C., \& Stacey, K. (2006, Haziran). Students' conceptions of $m$ and $c$ : How to tune a linear function. Paper presented at the Proceedings of the 30th Conference of the International Group for the Psychology of Mathematics Education, Prague.

Biembengut, M. S. (2007). Modelling and applications in primary education. In P. Galbraith, H.-W. Henn, \& M. Niss (Eds.), Modelling and applications in mathematics education (pp. 451-456). New York: Springer.

Bilen, N., \& Ciltas, A. (2015). Evaluation of mathematical models and modeling in the fifth-grade mathematics curriculum based on teachers' views. e-Kafkas Journal of Educational Research, 2(2), 40-54.

Blum, W. (1993). Mathematical modelling in mathematics education and instruction. In T. Breiteig (Ed.), Teaching and learning mathematics in context (pp. 3-14). Chichester: Ellis Horwood Ltd.

Blum, W., \& Leiss, D. (2005). "Filling Up" The Problem of Independence-Preserving Teacher Interventions in Lessons With Demanding Modelling Tasks. Paper presented at the CERME 4-Proceedings of the Fourth Congress of the European Society for Research in Mathematics Education.

Boaler, J. (2001). Mathematical modelling and new theories of learning. Teaching Mathematics and Its Applications: International Journal of the IMA, 2O(3), 121-128.

Buyukozturk, S., Cakmak, E. K., Akgun, O. E., Karadeniz, S., \& Demirel, F. (2014). Scientific Research Methods (Vol. 17). Ankara: Pegem Akademi.

Deniz, D., \& Akgün, L. (2016). The sufficiency of high school mathematics teachers' to design activities appropriate to Model Eliciting Activities design principles. KaraelmasJournal of Educational Sciences, 4(1), 1-14.

Disbudak, K. (2014). Modeling activities for 6th grade students' academic achievement and its impact on attitudes towards mathematics. (Unpublished Master Thesis), Gazi Üniversity, Ankara.

Doerr, H. M., \& English, L. D. (2003). A modeling perspective on students' mathematical reasoning about data. Journal for Research in Mathematics Education, 34(2), 110-136.

Doruk, B. K. (2010). The Effect of Mathematical Modeling on Transferring Mathematics Into Daily Life. (PhD. Thesis), Hacettepe Üniversity, Ankara.

Doruk, B. K. (2014). An Effective Tool for the Development of Communication Skills: Mathematical Modeling Activities. MATDER Journal of Mathematics Education, 1(1), 1-12.

Doruk, B. K., \& Umay, A. (2011). The Effect of Mathematical Modeling on Transferring Mathematics Into Daily LIfe. Hacettepe University Journal of Education, 41(41), 124-135.

English, L. D. (2004). Mathematical modeling in the primary 
school. In I. Putt, R. Faragher, \& M. McLean (Eds.), Mathematics education for the third millennium: Towards 2010 (pp. 207-214). James Cook University: Mathematics Education Research Group of Australasia. .

Erbas, A. K., Kertil, M., Cetinkaya, B., Alacaci, C., Cakiroglu, E., \& Bas, S. (2014). Mathematical modeling in mathematics education: Basic concepts and approaches. Educational Sciences: Theory \& Practice, 14(4), 1607-1627.

Galbraith, P. (2012). Models of modelling: genres, purposes or perspectives. Journal of Mathematical Modelling and application, 1(5), 3-16.

Hidiroglu, C. N., Tekin Dede, A., Kula, S., \& Bukova Güzel, E. (2014). Examining students' solutions regarding the comet problem in theframe of mathematical modeling process. Mehmet Akif Ersoy University Journal of Education Faculty, 31, 1-17.

Kaiser, G., \& Sriraman, B. (2006). A global survey of international perspectives on modelling in mathematics education. $Z D M$, 38(3), 302-310.

Kal, F. M. (2013). The impact of mathematical modelling activitties to the attitudes of primary school 6th grade students in solving maths problems. (Unpublished Master Thesis), Kocaeli Üniversity, Kocaeli.

Kandemir, M. A. (2011). Analysis of the effect of modelling activities on students? Affective features and thoughts on problem solving and technology. (Unpublished Doctoral Thesis), Balıkesir üniversity, Balıkesir.

Kaput, J. J. (1987). Representation systems and mathematics. Problems of representation in the teaching and learning of mathematics, 19, 26-40.

Karabork, M. A. (2016). Effects of Model Eliciting Activities on Seventh Grade Students' Mathematics Success and Students' Views about These Activities. (Yayınlanmamış Yüksek Lisans Tezi,), Unpublished Master Thesis, Bolu.

Karali, D., \& Durmus, S. (2015). Primary School Pre-service Mathematics Teachers' Views on Mathematical Modeling. Eurasia Journal of Mathematics, Science \& Technology Education, 11(4), 803-815.

Kertil, M. (2008). Investigating problem solving ability of pre-service mathematics teachers in modeling process. (Unpublished Master Thesis), Marmara Üniversity, İstanbul.

Lesh, R., \& Doerr, H. (2003). Foundations of a model and modeling perspective on mathematics teaching, learning, and problem solving. In R. Lesh \& H. Doerr (Eds.), Beyond Constructivism Models and Modeling Perspectives on Mathematics Problem Solving, Learning, and Teaching (Vol. 5, pp. 3-34). Mahwah, New Jersey: London.

MoNE. (2017a). Elementary and Midddle School Mathematics Curriculum (Elementary and Middle School Teaching Program of Mathematics (1-8. Grades). Ankara: National Education Publisher.

MoNE. (2017b). Elementary and Midddle School Mathematics Curriculum (İkokul ve Ortaokul Matematik Dersi (1-8. sınıflar) Öğretim programı) Ankara: Milli Eğitim Bakanlığ Talim ve Terbiye Kurulu Başkanlığı Milli Eğitim Basımevi.

NCTM. (2000). Principles and standards for school mathematics (Vol. 1).

Nufus, H., \& Mursalin, M. (2020). Improving Students'
Problem Solving Ability and Mathematical Communication through the Application of Problem Based Learning. Electronic Journal of Education, Social Economics and Technology, 1(1), 43-48. DOI: 10.33122/ejeset.v1i1.8

Nuraina, N., \& Mursalin, M. (2018). Improving Students' Mathematical Communication Skills Through Learning Start Learning Models With A Question on Pythagoras. Malikussaleh Journal of Mathematics Learning (MJML), 1(2), 44-47.

Pierce, R. U., \& Stacey, K. C. (2006). Enhancing the image of mathematics by association with simple pleasures from real world contexts. $Z D M, 38(3), 214-225$.

Rind, A. A., \& Mughal, S. H. (2020). An Analysis of Pakistan's National Curriculum of Mathematics at Secondary level. Electronic Journal of Education, Social Economics and Technology, 1(1), 39-42. DOI: 10.33122/ejeset.v1i1.4

Sagirli, M. O. (2010). The effects of mathematical modelling method on derivative topic on secondary education students? Academic achievements and self-regulation skills. (PhD. Thesis), Atatürk Üniversity, Erzurum.

Sagirli, M. O., Kirmaci, U., \& Bulut, S. (2010). The effects of mathematical modelling method on secondary school students' academic achievements and self-regulated learning skills. Erzincan University Journal of Science and Technology, 3(2), 221-247.

Samsuriadi, S., \& Imron, M. A. (2019). The Effect of Think Pair Share (TPS) Learning Model With Problem Solving Approach on the Student's Math Communication in MA DA Jarowaru. Malikussaleh Journal of Mathematics Learning (MJML), 2(1), 9-12.

Sandalci, Y. (2013). The impact of teaching algebra through mathematical modeling on 6-grade students' academic success and how they correlate mathematics with daily life. (Unpublished Master Thesis), Recep Tayyip Erdoğan Üniversity, Rize.

Schumacher, S., \& Mcmillan, J. (2006). Research in Education Evidence-Based Inquiry. Boston: Pearson Education.

Stipek, D. J. (2002). Motivation to learn: From theory to practice (Vol. 5). Needham Heights: Allyn \& Bacon; 4 edition

Tekin Dede, A., \& Bukova Güzel, E. (2013). Examining the mathematics teachers' design process of the Model Eliciting Activity: Obesity problem. Elementary Education Online, 12(4), 1100-1119.

Tekin Dede, A., \& Bukova Güzel, E. (2014). Model elıcıtıng activities: The theoretical structure and its example. Ondokuz mayis University Journal of Education, 33(1), 95-112.

Van De Walle, J. A., Karp, K. S., \& Bay-Williams, J. M. (2012). Elemantary and Middle School Mathematics Teaching Developmentally (S. Durmus, Trans. Vol. 7). Ankara: Nobel Akademic Publications.

Verschaffel, L., De Corte, E., Lasure, S., Van Vaerenbergh, G., Bogaerts, H., \& Ratinckx, E. (1999). Learning to solve mathematical application problems: A design experiment with fifth graders. Mathematical thinking and learning, 1(3), 195-229.

Verschaffel, L., De Corte, E., \& Vierstraete, H. (1999). Upper Elementary School Pupils' Difficulties in Modeling and 
Solving Nonstandard Additive Word Problems Involving Ordinal Numbers. Journal for research in mathematics education, 30(3), 265-285.

Yıldırım, A., \& Şimşek, H. (2013). Qualitative Research Methods in Social Sciences. Ankara: Seckin Publication.

Yildirim, Z., \& Isik, A. (2015). The effects of mathematical modelling activities to academic achievement of the fifth grade students in mathematics course. Kastamonu Journal of Education, 23(2), 581-600.

Zawojewski, J., \& Lesh, R. (2003). A models and modeling perspective on problem solving. In R. Lesh, H. M. Doerr, G. Carmona, \& M. Hjalmarson (Eds.), Beyond constructivism: Models and modeling perspectives on mathematics problem solving, learning, and teaching (pp. 317-336). New Jersey: London. 